\title{
THE INFLUENCE OF WEB QUALITY ON CLIENT'S INTERNET BANKING ADOPTION MEDIATED BY PERCEIVED EASE OF USE ON BANK JATIM SURABAYA
}

\author{
${ }^{1}$ Eriet Erawati, ${ }^{2}$ Nurul Aini, ${ }^{3}$ Joko Suyono, ${ }^{4}$ Damarsari Ratnasahara \\ Narotama University, Indonesia \\ Email : ${ }^{1}$ eriet.erawati@ narotama.ac.id, ${ }^{2}$ eriet.erawati@narotama.ac.id, ${ }^{3}$ eriet.erawati@narotama.ac.id, \\ eriet.erawati@narotama.ac.id
}

\begin{abstract}
Purpose: This paper aims to analyze the influence of web quality on the client's e-banking adoption through the mediation of perceived ease of use.

Design/methodology/approach: The method used is statistic-descriptive and the design used is cross sectional.

Findings: 3 out of 7 hypotheses are rejected while the other 4 is accepted.

Research limitations/implications: Variables considered in this study are perceived ease of use in technology acceptance model, web quality, accessibility, and internet banking adoption. The samples are a number of customers (60 respondents) in Bank Jatim Surabaya that were chosen using purposive sampling.

Practical implications: Results show that the hypotheses proposed are proven by the equation.

Originality/value: This paper is original.

Paper type: This paper can be categorized as a case study.
\end{abstract}

Keyword: Accessibility, Internet banking adoption, Perceived ease of use, Web quality

Received: July $14^{\text {th }}, 2020$

Revised: September $5^{\text {th }}, 2020$

Published: September $30^{\text {th }}, 2020$

\section{INTRODUCTION}

Online banking has become one of the essential services in the banking industry nowadays. Many banks had made online banking service for their own in order to ease their customers. Bank Jatim Surabaya is one of the banks that provides such service and recorded from the internal data of the bank, there is significant raise of customers using e-banking. See the table below to see the statistics.

Online banking, or e-banking, had started to emerge as one of the facilities proposed by banks in order to ease the customer's accessibility in doing transactions. Aside from easier access to their banking account, customer's can also do faster transactions because the activity would only require by phone, which means that the customers could use their phone in order to do transactions - no longer going to the bank. Moreover, the emergence of online banking also triggers the increase in internet and mobile device connectivity in which related to the online usage of online banking facility (Sundaram, Thomas and Agilandeeswari, 2019).

Basing on that raise, it could be inferred that e-banking is indeed advantageous to the customers. However, there are also external factors that are involved in the process such as web quality and accessibility (Al-Ghaith, Sanzogni and Sandhu, 2010). Technology Acceptance Model (TAM) is a popular model used in many studies in the process of technology information adoption including internet banking. According to TAM, user's perceived ease of use is the main determiner of adoption behavior and lastly is by technology (Lin and Lu, 2011). 
Table 1. Bank Jatim E-Banking Users Yearly

\begin{tabular}{lllll}
\hline Year & Users & $\%$ & Individual & Corporate \\
\hline 2016 & 5.654 & - & & \\
2017 & 7.203 & $27.40 \%$ & 5.919 & 1.284 \\
2018 & 9.359 & $29.93 \%$ & 6.712 & 2.647 \\
2019 & 11.254 & $20.25 \%$ & 8.284 & 2.970 \\
\hline
\end{tabular}

Source : Bank Jatim's Internal Data

A good web quality could not only influence the customer's transaction decision but also becomes one of the reasons for the customer to decide whether they will do a transaction or not (Huang and Benyoucef, 2013). This research aims to accommodate the gap in the previous studies by focusing on the web quality, system accessibility, customer's perceived ease of use, and adoption will in internet banking.

\section{A. Previous Study}

There were previous studies that considered the factors above such as (Kusuma and Susilowati, 2007), (Isti Hanum, 2017), and (Fragata, 2010). Pratiwi had researched about the influence of trust, perceived ease of use, security, web service quality and e-banking adoption risk; among all the variables, only risk is the one with negative influence. There is also (Alalwan et al., 2018) that analyzed the factors influencing the customer in using internet banking; showing that comfort, accessibility, features providence, privacy, speed, fee, management, designs and contents could significantly influence the customer's adoption will.

\section{B. Hypotheses}

$\mathrm{H}_{1} \quad$ : Web Quality influence positively on Perceived Ease of Use

$\mathrm{H}_{2} \quad$ : Accessibility influences positively on Perceived Ease of Use

$\mathrm{H}_{3} \quad$ : Web Qualit influences positively on customer's e-banking Adoption

$\mathrm{H}_{4} \quad$ : Accessibility influences positively on customer's e-banking Adoption

$\mathrm{H}_{5} \quad$ : Perceived of Use influences positively on customer's e-banking Adoption

$\mathrm{H}_{5 \mathrm{a}} \quad$ : Web Quality influences positively on customer's e-banking Adoption through Perceived Ease of Use

$\mathrm{H}_{5 \mathrm{~b}} \quad$ : Accessibility influences positively on customer's e-banking Adoption through Perceived Ease Use

\section{METHODOLOGY}

\section{A. Research Design}

This study is cross sectional in which the data collection from certain sample is implemented only once. This research is also a non-experimental research in which there is no manipulation in the variables analyzed because the manifestation already happened (Kerlinger and Lee, 2010).

\section{B. Population and Sample}

The population for this research is the customers of Bank Jatim Surabaya corporate which total is 479 company including small, middle, and big category. The samples are 60 respondents $(5 \times 12$ indicators) from Bank Jatim Surabaya that are customers. The samples are collected using purposive sampling. There are also criterias needed for the samples which include: (a) Respondent is a customer that had became a customer for a year or more, (b) Respondent had adopt the e-banking service (because customer's that had adopt is assumed to be willingly adopt before), and (c) Respondent is living in Surabaya.

The data collection uses questionnaires which is filled with questions appropriate with the research's variable. Scale value shows the respondents' Agreement and Disagreement level towards the questions asked. The measurement scale of the five factors above reaches 5 scales that include: 1-Highly disagree, 2Disagree, 3-More or less agree, 4-Agree, and 5-Highly agree. 


\section{Research Variable}

\section{X1 : Web Quality}

It is the quality of the internet banking system and it involves fast access, easy navigation, also complete presentation on the site unity (Udo, Bagchi and Kirs, 2010). The look and structure of the site that could influence the customer's interest in doing transactions. The look, content quality, specific content, and technical appropriateness are the indicators adapted from (Gregg and Walczak, 2010).

\section{X2 : Acessibility}

The ease and fast access of e-banking information system. The indicators are adapted from Cussoy et al. (2012) which include whenever and wherever the use of e-banking.

\section{Z : Perceived Ease of Use}

A phase in which the customer believes that the use of online banking could lower the effort of customers workload. The indicators are adapted from (Giovanis, Binioris and Polychronopoulos, 2012). which include the ease in the tutorial, the ease in using the internet banking to finish banking tasks, and the trust that internet banking is easy.

\section{Y : E-banking Adoption Will}

Refers to how high the customer wants to do internet banking. The indicators are also adapted from (Giovanis, Binioris and Polychronopoulos, 2012) which include the desire in internet banking transactions, the desire in using internet banking facility, and planning to use the internet banking.

\section{Data Analysis Method}

Partial Least Square will be used, in which the data that will be analyzed does not always have to fulfill the criteria stated. PLS is a non-parametric prediction and will include (1) an outer model that will be evaluated using convergent validity and its indicators, composite reliability for block indicator; and, (2) inner model in which is evaluated by looking at the percentage of variance explained, which is by looking at the $\mathrm{R}^{2}$ (R Square) to construct latent dependent and measuring the coefficiency of its structural track. Stability from this estimation is evaluated using $\mathrm{t}$ statistcis test that is received through bootrapping procedure. (Ghozali, 2018).

\section{E. Hypotheses Evaluation}

The hypotheses evaluation is also done by comparing the value of $t$ statistics with $t$ table. If the $t$ statistics is higher than $t$ table (1.96), that signs that there is significant influence between a variable towards other variables. On the other hand, if it is lower than that number, then there is no significant influence.

\section{RESULTS AND DISCUSSION}

\section{A. Partial Least Square Analysis}

Reliability and Validity Test

1. Convergent Validity Test

Outer model evaluation using convergent validity of loading factor for each variables targeted by > 0.50 . If the value is higher or is on the same value, it is considered an indicator, however, if it is not, it would not be considered as an indicator.

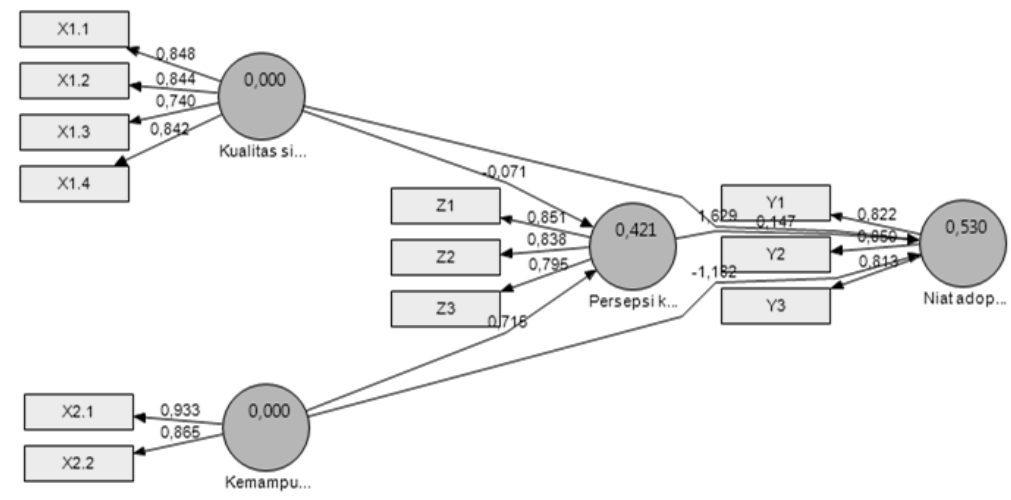

Figure 1 - Outer Model

The Influence Of Web Quality On Client's Internet Banking Adoption Mediated By Perceived 
According to the figure above, the variables has multiple indicators. These indicators are included if they fulfill the convergent validity of loading factor value of $>0.7$ for Web Quality, Accessibility, Perceived Ease of Use, and e-banking Adoption Will. The indicators include:
a. Web Quality $(\mathrm{X} 1)$ by 4 indicators $-\mathrm{X} 1.1=0.847 ; \mathrm{X} 1.2=0.844 ; \mathrm{X} 1.3=0.740 ; \mathrm{X} 1.4=0.841$;
b. Accessibility (X2) by 2 indicators $-\mathrm{X} 2.1=0.933 ; \mathrm{X} 2.2=0.864$;
c. Perceived Ease of Use $(\mathrm{Z})$ by 3 indicators $-\mathrm{Z} 1=0.850 ; \mathrm{Z} 2=0.838 ; \mathrm{Z3}=0.794$;
d. Adoption Will $(\mathrm{Y})$ by 3 indicators $-\mathrm{Y} 1=0.822 ; \mathrm{Y} 2=0.849 ; \mathrm{Y} 3=0.814$.

\section{Discriminant Vailidity}

The next evaluation is by comparing between discriminant validity and square root of average variance extracted (AVE), the measurement model is valued basing on cross loading with constract. If the constract coleration with every indicator is higher than other constract, then the laten constract predicts the indicator is better than other constract. If the value is higher than the coleration value between constracts, then a better discriminant validity will be reached (if the AVE is $>0,7$ ).

Table 2. AVE criteria measurement

\begin{tabular}{ll}
\hline & AVE \\
\hline Web Quality (X1) & 0.809405 \\
Accessibility (X2) & 0.672019 \\
Adoption Will (Y) & 0.686203 \\
Perceived Ease of Use (Z) & 0.685952 \\
\hline
\end{tabular}

Source : PLS

From the measurement above, it could be seen that only one variable that fits the standard in PLS 3.2.7 that has value more than $>0.7$.

\section{Composite Reliability Test}

To decided on the composite reliability, the value $>0,8$ is considered high reliability and $>0,6$ is decent reliability. The result of test could be seen below.

Table 3. Composite reliability measurement

\begin{tabular}{ll}
\hline & Composite Reliability \\
\hline $\mathrm{X} 1$ & 0.890 \\
$\mathrm{X} 2$ & 0.894 \\
$\mathrm{Y}$ & 0.867 \\
$\mathrm{Z}$ & 0.867 \\
\hline
\end{tabular}

4. Cronbach Alpha Test

This test is to strengthen the reliability test in which consistency of every answer is tested. The condition for this test is it will be considered good if $\alpha \geq 0,6$ and it will be considered decent if $\alpha \geq 0,3$. Below is the Cronbach test results.

Table 4. Cronbach Alpha measurement

\begin{tabular}{ll}
\hline & Cronbachs Alpha \\
\hline $\mathrm{X} 1$ & 0.770 \\
$\mathrm{X} 2$ & 0.836 \\
$\mathrm{Y}$ & 0.773 \\
$\mathrm{Z}$ & 0.770 \\
\hline
\end{tabular}

\section{Inner Model}

The value of $\mathrm{R}$-square $>0$ shows model has predictive relevance, however, if it shows $\leq 0$ then it means that the model does not have enough predictive relevance. Below is th table for the inner model using PLS. 
Table 4. R Square

\begin{tabular}{lll}
\hline & R Square & Adjusted R Square \\
$\mathrm{Y}$ & 0.421 & 0.530 \\
\hline
\end{tabular}

The R-square table above has reached 0.421 — explained by variable web quality (X1), accessibility (X2), and perceived ease of use $(\mathrm{Z})$ that gives value 0.421 that could be inferred that the latent dependent variable is $42.1 \%$, while the rest $57.9 \%$ is explained by variables outside the research's limit. Then, the Adjusted R value 0.530 or $53 \%$, which means $47 \%$ variation happening in variable Y could be explained by latent dependent variable.

6. Bootsrapping

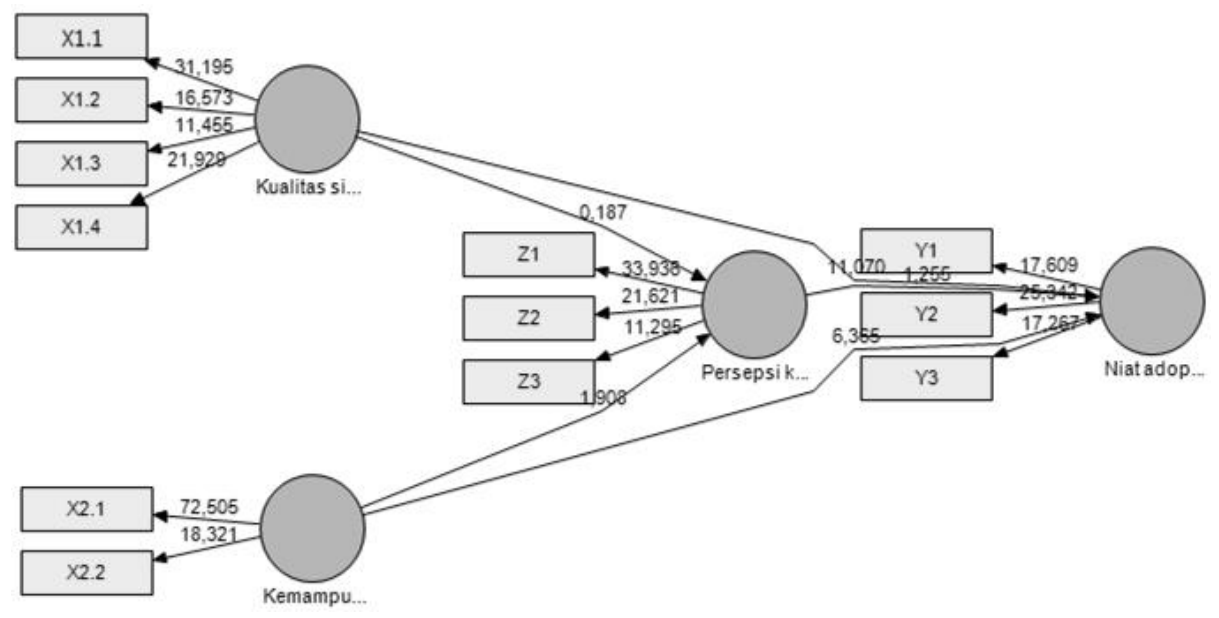

Figure 2. Bootstrapping PLS

7. Hypotheses Tests

The significance level $(\alpha)$ of $5 \%$ is included in the criteria for hypthosesis. The conditions are: (1) if the value of $\mathrm{t}$ count $>\mathrm{t}$ table (1.96), then the hypothesis will be accepted; and (2) if the value of $\mathrm{t}$ count $<\mathrm{t}$ table (1.96), the hypothesis will be rejected. See below for the tests.

Table 5. Bootstrapping Hypotheses $1-7$

\begin{tabular}{|c|c|c|c|c|c|c|}
\hline Hypotheses & Variables & $\begin{array}{l}\text { Original } \\
\text { Sample (O) }\end{array}$ & $\begin{array}{l}\text { Sample } \\
\text { Mean (M) }\end{array}$ & $\begin{array}{l}\text { Standard } \\
\text { Deviation } \\
\text { (STDEV) }\end{array}$ & $\begin{array}{l}\text { Standard } \\
\text { Error } \\
\text { (STERR) }\end{array}$ & $\begin{array}{l}\text { Statistics } \\
\text { (|O/STERR } \mid)\end{array}$ \\
\hline H1 & $\mathrm{X} 1 \rightarrow \mathrm{Z}$ & -0.070 & -0.138 & 0.37 & 0.378 & 0.187 \\
\hline $\mathrm{H} 2$ & $\mathrm{X} 2 \rightarrow \mathrm{Z}$ & 0.714 & 0.792 & 0.374 & 0.374 & 1.908 \\
\hline H3 & $\mathrm{X} 1 \rightarrow \mathrm{Y}$ & 1.628 & 1.605 & 0.147 & 0.147 & 11.070 \\
\hline H4 & $\mathrm{X} 2 \rightarrow \mathrm{Y}$ & -1.181 & -.148 & 0.185 & 0.185 & 6.365 \\
\hline H5 & $\mathrm{Z} \rightarrow \mathrm{Y}$ & 0.146 & 0.139 & 0.116 & 0.116 & 1.255 \\
\hline H6 & $\mathrm{X} 1 * \mathrm{Z} \rightarrow \mathrm{Y}$ & 1.361 & 1.333 & 0.170 & 0.170 & 8.002 \\
\hline H7 & $\mathrm{X} 2 * \mathrm{Z} \rightarrow \mathrm{Y}$ & -2.605 & -2.460 & 0.780 & 0.780 & 3.337 \\
\hline
\end{tabular}

Source: PLS

1. The T-statistic of $\mathrm{H} 1$ is lower than the t-table (1.96), which means $\mathrm{H} 1$ is not significant and is rejected.

2. The T-statistic of $\mathrm{H} 2$ is 1.908 , and with $\mathrm{t}$-statsitic $>\mathrm{t}$-table $(5 \%=1.96)$. Therefore, $\mathrm{H} 2$ is accepted.

3. The original sample and T-statistics of $\mathrm{H} 3$ are 1.628 and 11.070 respectively, thus, $\mathrm{H} 3$ is rejected.

4. The original sample and T-statistics of H4 are -1.181 and 6.365 respectively, thus, H3 is accepted.

5. The original sample and T-statistics of H5 are 0.146 and 1.255 respectively, thus, H5 is rejected.

6. The original sample and T-statistics of H6 are 1.361 and 8.002 respectively, thus, H6 is accepted. 
7. The original sample and T-statistics of H3 are -2.605 and 3.337 respectively, thus, $\mathrm{H} 7$ is accepted

\section{CONCLUSION}

In conclusion, this study shows that:

1. Web Quality given by Bank Jatim Surabaya has not ease the customer in using internet banking.

2. Accessibility is not only related to the ability to use the system, but also the ability of physical access of internet connection.

3. A good Web Quality is the one that could fulfill the customers' expectation both in the present and future.

4. If accesibility to the bank's e-banking system is smooth and the transactions done are effortless, then the e-banking adoption will could increase.

5. Bank Jatim's Perceived Ease of Use has not ease the customer's workload.

6. Internet banking website with features such as search or user-friendly navigation could help the user in the transaction, which could positively influence the customer in using it more.

7. If the customer could smoothly access the bank's website and call the bank's representative whenever there is problem, also if the transactions are easily done, then the customer's e-banking adoption will could increase.

\section{ACKNOWLEDGMENTS}

This work has no conflict of interest.

\section{REFERENCES}

Al-Ghaith, W., Sanzogni, L. and Sandhu, K. (2010) 'Factors Influencing the Adoption and Usage of Online Services in Saudi Arabia', The Electronic Journal of Information Systems in Developing Countries, 40(1), pp. 1-32. doi: 10.1002/j.1681-4835.2010.tb00283.x.

Alalwan, A. A. et al. (2018) 'Examining factors influencing Jordanian customers' intentions and adoption of internet banking: Extending UTAUT2 with risk', Journal of Retailing and Consumer Services, 40(1), pp. 125-138. doi: 10.1016/j.jretconser.2017.08.026.

Fragata, anaBela oliveira D. silva (2010) Departamento De aDministracion y economia De la empresa. De salamanca.

Ghozali, I. (2018) Equation Modeling Metode Alternatif dengan Partial Least Square. 12th edn. Semarang: Badan Penerbit Universitas Diponegoro.

Giovanis, A. N., Binioris, S. and Polychronopoulos, G. (2012) 'An extension of TAM model with IDT and security/privacy risk in the adoption of internet banking services in Greece', EuroMed Journal of Business, 7(1), pp. 24-53. doi: 10.1108/14502191211225365.

Gregg, D. G. and Walczak, S. (2010) 'The relationship between website quality, trust and price premiums at online auctions', Electronic Commerce Research, 10(1), pp. 1-25. doi: 10.1007/s10660-010-9044-2.

Huang, Z. and Benyoucef, M. (2013) 'From e-commerce to social commerce: A close look at design features', Electronic Commerce Research and Applications, 12(1), pp. 246-259. doi: 10.1016/j.elerap.2012.12.003.

Isti Hanum, P. (2017) 'Pengaruh Kepercayaan, Kemudahan Penggunaan, Keamanan, Kualitas Layanan Website Dan Risiko Terhadap Adopsi Internet Banking Cimb Niaga Di Surrabaya', Sekolah Tinggi Ilmu Ekonomi Perbanas Surabaya 2017.

Kerlinger, F. N. and Lee, H. . (2010) Foundations of Behavioral Research. 4th edn. Florida: Harcourt, Inc.

Kusuma, H. and Susilowati, D. (2007) Determinan Pengadopsian Layanan Internet Banking: Perspektif Konsumen Perbankan Daerah Istimewa Yogyakarta, Jurnal Akuntansi dan Auditing Indonesia. Available at: https://journal.uii.ac.id/JAAI/article/view/216 (Accessed: 13 October 2020).

Lin, K. Y. and Lu, H. P. (2011) 'Why people use social networking sites: An empirical study integrating network externalities and motivation theory', Computers in Human Behavior, 27(3), pp. 1152-1161. doi: 10.1016/j.chb.2010.12.009.

The Influence Of Web Quality On Client's Internet Banking Adoption Mediated By Perceived 
Sundaram, N., Thomas, C. and Agilandeeswari, L. (2019) 'Science \& Technology A Review: Customers Online Security on Usage of Banking Technologies in Smartphones and Computers', Pertanika J. Sci. \& Technol, 27(1), pp. 1-31.

Udo, G. J., Bagchi, K. K. and Kirs, P. J. (2010) 'An assessment of customers' e-service quality perception, satisfaction and intention', International Journal of Information Management, 30(6), pp. 481-492. doi: 10.1016/j.ijinfomgt.2010.03.005. 